
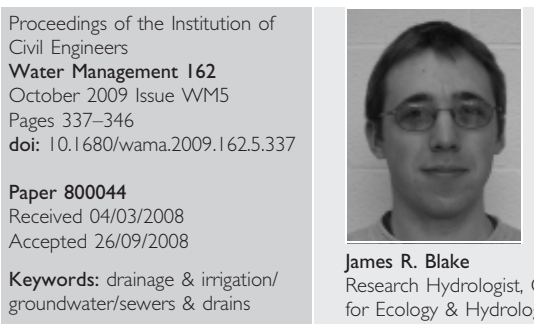

James R. Blake

Research Hydrologist, Centre

for Ecology \& Hydrology,

Wallingford, UK

\title{
Soakage testing: modelling the effect of antecedent hydrology
}

\author{
J. R. Blake MSci, PhD
}

Current design methods for sustainable drainage system infiltration devices such as soakaways, permeable pavements and infiltration basins require knowledge of the empirical soil infiltration coefficient, which is determined using a soakage test procedure. However, the control that seasonal antecedent hydrological conditions, specifically unsaturated zone soil moisture and water table position, have on the infiltration coefficient is uncertain. This paper uses exploratory numerical modelling to investigate this uncertainty. The results show that antecedent water table position has a significant effect on the infiltration coefficient, while for a properly conducted test the seasonal antecedent soil moisture is less important. To avoid overestimating the infiltration coefficient, soakage testing should ideally be performed under the most onerous hydrological conditions and three successive drain downs must be used. Model outputs such as those presented can be used to reduce the design infiltration coefficient to account for tests made during periods of lower groundwater level and higher design water table positions. Additionally, the current infiltration coefficient calculation is shown to be biased towards the initial, more rapid, infiltration rate. Therefore, an alternative full-depth infiltration coefficient calculation is proposed. Finally, a potential detrimental feedback is hypothesised between infiltration device performance and groundwater mounding. Significant design implications are discussed.

\section{NOTATION}

$a_{p 50} \quad$ wetted internal surface area (sides and base) of soakage test pit at 50\% of effective depth $\left(\mathrm{m}^{2}\right)$

$H \quad$ hydraulic head $(\mathrm{m})$

$h \quad$ pore water pressure head $(\mathrm{m})$

$K \quad$ hydraulic conductivity $(\mathrm{m} / \mathrm{s})$

$K_{\text {sat }} \quad$ saturated hydraulic conductivity $(\mathrm{m} / \mathrm{s})$

$l \quad$ Mualem pore-connectivity parameter

$m_{\mathrm{vg}} \quad$ van Genuchten-Mualem curve-fitting parameter

$n_{\mathrm{bc}} \quad$ Brooks and Corey pore-size distribution parameter

$n_{\mathrm{vg}} \quad$ van Genuchten pore-size distribution parameter

$q \quad$ soakage test empirical soil infiltration coefficient $(\mathrm{m} / \mathrm{h})$

$S \quad$ a source term $\left(\mathrm{s}^{-1}\right)$

$t_{p 75-25}$ time for soakage test pit water level to fall from 75 to 25\% effective depth (h) $t_{p 100-0}$ time for soakage test pit water level to fall from 100 to $0 \%$ effective depth $(\mathrm{h})$

$V_{p 75-25}$ volume of soakage test pit between 75 and 25\% of effective depth $\left(\mathrm{m}^{3}\right)$

$V_{p 100-0}$ volume of soakage test pit between 100 and $0 \%$ of effective depth $\left(\mathrm{m}^{3}\right)$

$z \quad$ elevation $(\mathrm{m})$

$\alpha_{\mathrm{bc}} \quad$ Brooks and Corey empirical parameter; inverse of air entry pressure head $\left(\mathrm{m}^{-1}\right)$

$\alpha_{\mathrm{vg}} \quad$ van Genuchten curve fitting parameter $\left(\mathrm{m}^{-1}\right)$

$\theta \quad$ volumetric water content $\left(\mathrm{m}^{3} / \mathrm{m}^{3}\right)$

$\theta_{\mathrm{s}} \quad$ saturated volumetric water content $\left(\mathrm{m}^{3} / \mathrm{m}^{3}\right)$

$\theta_{\mathrm{r}} \quad$ residual volumetric water content $\left(\mathrm{m}^{3} / \mathrm{m}^{3}\right)$

\section{INTRODUCTION}

Infiltration drainage, a component of sustainable drainage systems (SuDS), is promoted in current planning guidance ${ }^{1}$ and building regulations. ${ }^{2}$ Current design methods for infiltration devices such as soakaways, permeable pavements and infiltration basins require knowledge of the empirical soil infiltration coefficient, $q$, as determined in the field using a soakage test procedure. ${ }^{3-5}$ UK best practice for soakage testing stems from Building Research Establishment (BRE) digest 365, ${ }^{3}$ which describes the following procedure.

(a) Excavate a test pit to the same depth as the proposed soakaway (typically $1.5-2.5 \mathrm{~m}$ ), of width $0.3-1.0 \mathrm{~m}$, length $1.0-3.0 \mathrm{~m}$ and with vertical sides.

(b) Rapidly fill the pit with water to the maximum effective depth (i.e. the invert level of the proposed input pipe(s)).

(c) Allow the pit to drain, recording water level fall over time.

(d) Repeat the filling/emptying cycle twice more on the same or consecutive days.

(e) For each set of drain down data, calculate the soil infiltration coefficient using

$$
q=V_{p 75-25} /\left(a_{p 50} \times t_{p 75-25}\right)
$$

where $V_{p 75-25}$ is the volume of the pit between 75 and $25 \%$ of the effective depth, $a_{p 50}$ is the wetted internal surface area (sides and base) of the pit at 50\% of the effective depth and $t_{p 75-25}$ is the time for the water level to fall from 75 to $25 \%$ of the effective pit depth. The smallest value of $q$ from the three repetitions should be used for design. 
The procedure outlined in the Construction Industry Research and Information Association (CIRIA) report $156^{4}$ is nearidentical, except that the test is extended to infiltration devices in general (noting the requirement for shallower pits for planar devices such as permeable pavements), minimum pit volumes are recommended $\left(0.5 \mathrm{~m}^{3}\right.$ for drained areas up to $100 \mathrm{~m}^{2}$, otherwise $1 \mathrm{~m}^{3}$ ) and fillings should preferably be carried out on the same day. The CIRIA SuDS manual ${ }^{5}$ follows the above advice, but increases the minimum pit volume to $2 \mathrm{~m}^{3}$ for areas over $100 \mathrm{~m}^{2}$. This paper does not consider the soakage test procedure outlined in the current building regulations ${ }^{2}$ as it uses a significantly smaller test pit; neither is the constant head soakage test suggested by Watkins ${ }^{6}$ considered as it is not in current practice.

The soil infiltration coefficient is critical in the design of infiltration devices and there is recognition that antecedent hydrological conditions might affect its magnitude. For example, BRE digest $365^{3}$ suggests assessing the effect of groundwater variations on long-term percolation and advises that the seasonal high water table should remain below the soakaway base (an alternative suggestion is at least $1 \mathrm{~m}$ below the base, ${ }^{4,5}$ to provide effective pollution control). Pratt ${ }^{7}$ states that the soakage test infiltration rate might be affected by seasonal soil moisture variations and poses the question 'what account should be taken of any effect due to the time of year?'. One of the soakage testing uncertainties listed in CIRIA report $156^{4}$ is 'would the infiltration coefficient be different for different soil moisture conditions?' (see also the SuDS manual ${ }^{5}$ ). To reduce these uncertainties, this research aims to investigate the control that seasonal antecedent hydrological conditions, specifically unsaturated zone soil moisture and water table position, have on the soil infiltration coefficient determined using the current soakage test procedure.

To address the above aim, one might conduct a series of soakage tests in the same pit over an annual cycle, including monitoring of soil moisture and water table position. For example, Pratt ${ }^{7}$ cites limited soakage testing by Mantle, which showed that infiltration rates varied between a winter minimum and a summer maximum. However, in that study the rates do not appear to have been related to specific soil moisture and water table measurements. A field study would reflect the characteristics of a specific site, some of which (e.g. soil spatial variability) may be uncertain. This limits the ability to generalise the results. Furthermore, it would also be controlled by natural hydrological variability, meaning that a wide range of antecedent conditions may not occur during any given year. Therefore, an exploratory numerical sub-surface hydrological modelling approach has been adopted, allowing a wide range of antecedent hydrological conditions to be investigated.

Numerical sub-surface hydrological modelling has been used previously to investigate storm water infiltration device behaviour, using flow assumptions including steady-state saturated, ${ }^{8}$ steady-state saturated-unsaturated ${ }^{9}$ and transient saturated-unsaturated with fixed head infiltration. ${ }^{10}$ Transient saturated-unsaturated modelling has also highlighted the importance of the unsaturated zone on groundwater mounding caused by artificial recharge. ${ }^{11,12}$ To the best of the author's knowledge, the only numerical sub- surface hydrological modelling of soakage tests is the pioneering work of Watkins, who included constant and falling head tests under transient saturated-unsaturated conditions. ${ }^{6}$ However, several limitations are apparent.

(a) The model discretisation, and possibly time-step, does not appear fine enough to capture the flow dynamics fully (as shown by oscillations in the pore water pressure head contours), reducing confidence in the results.

(b) The initial condition, and hence soil moisture, specification is rather unclear. The constant head simulations use quasihydrostatic conditions with an arbitrary limiting maximum suction (varying according to soil type). These were used because full hydrostatic initial conditions caused numerical solution problems. For falling head tests, the results of the constant head test were used as initial conditions, although justification for this is not given.

(c) The effect of water table position was not considered (it appears to have been fixed at $10 \mathrm{~m}$ below the surface, at the lower model boundary).

(d) The role of seasonal antecedent soil moisture was not investigated.

This work employs recent developments in numerical subsurface hydrological modelling, including adaptive timestepping and (hydro-)dynamic steady-state initial conditions, ${ }^{13}$ along with finer spatial discretisation facilitated by increased computational power, to allow better investigation of the effects of antecedent hydrology on soakage testing than has hitherto been possible. Different combinations of initial water table position and unsaturated zone soil moisture will be considered for typical soils in order to evaluate modelled values of the infiltration coefficient and hence its sensitivity to antecedent hydrology.

\section{THEORY AND MODEL SELECTION}

The soakage testing will be modelled using a code that can solve the 'mixed' version of the Richards equation for saturated-unsaturated flow of an incompressible fluid in incompressible media

\begin{tabular}{|l|l|}
\hline 2 & $\frac{\partial \theta}{\partial t}=\underline{\nabla}(\underline{\underline{K}} \underline{\nabla}(h+z))+S$ \\
\hline
\end{tabular}

where $t$ is time (s), $\theta$ is volumetric water content $\left(\mathrm{m}^{3} / \mathrm{m}^{3}\right), \underline{\underline{K}}$ is the hydraulic conductivity tensor $(\mathrm{m} / \mathrm{s}), h$ is pore water pressure head $(\mathrm{m}), z$ is elevation $(\mathrm{m})$ and $S$ is a source term $\left(\mathrm{s}^{-1}\right)$. This 'mixed' version (incorporating head and water content) has good mass conservation compared to alternative formulations. ${ }^{14}$ Equation 2 indicates that the empirical infiltration coefficient will be a function of the available water storage capacity and the hydraulic conductivity-both fundamental physical properties that vary in a non-linear manner with negative pressure head (alternatively termed tension or suction) - along with the hydraulic gradient driven by the height of water in the test pit.

The physically based distributed finite element (FE) code Feflow $^{\circledR} 5 \cdot 2^{15-17}$ was selected for the simulations as it includes a 'mixed' Richards equation solution, can simulate transient and steady-state conditions and has been extensively 
verified. ${ }^{16}$ The following model options were selected to balance solution speed, numerical convergence and mass conservation. For the transient simulations: Galerkin-based three-node triangular FE method; lumped mass matrices; analytic derivative for the capacity term; central weighting for the influence coefficient; Newton iteration scheme; preconditioned Lanczos BiCGSTABP iterative solver; adaptive time-stepping strategy using a forward Euler/backward Euler time integration; a maximum of 12 iterations per time-step and $1 \times 10^{-3}$ maximum error norm. ${ }^{17,18}$ The dynamic steady-state simulations employed the same options, except for: $h$-based Richards equation; Picard iteration scheme; and preconditioned conjugate gradient iterative solver. The modelling also assumes that there is no hysteresis, air entrapment or macropore flow, and that the sub-surface materials are isotropic and homogeneous. In this study the modelled soil types are unlikely to be highly anisotropic or macroporous.

\section{MODEL GEOMETRY, DISCRETISATION AND PARAMETERISATION}

The model geometry is shown in Figure 1. Gravity is in the negative $z$-direction. The section is rotated about the $z$-axis, giving a three-dimensional axisymmetric problem that can be modelled in two dimensions. Although current soakage testing procedures $^{3-5}$ specify a cuboid test pit, this cylindrical representation should not significantly affect the results. The pit plan area is also compatible with these specifications. The lower domain boundary is far enough below the test pit to simulate a number of water table positions. The distance to the right-hand domain boundary was specified to avoid propagation of boundary effects back to the area of interest. Figure 1 also shows the sub-domains and the FE mesh discretisation. There are $\sim 24000$ elements and the mesh is locally refined towards the pit and the surface. This provides a balance between resolution (high resolution is needed in areas

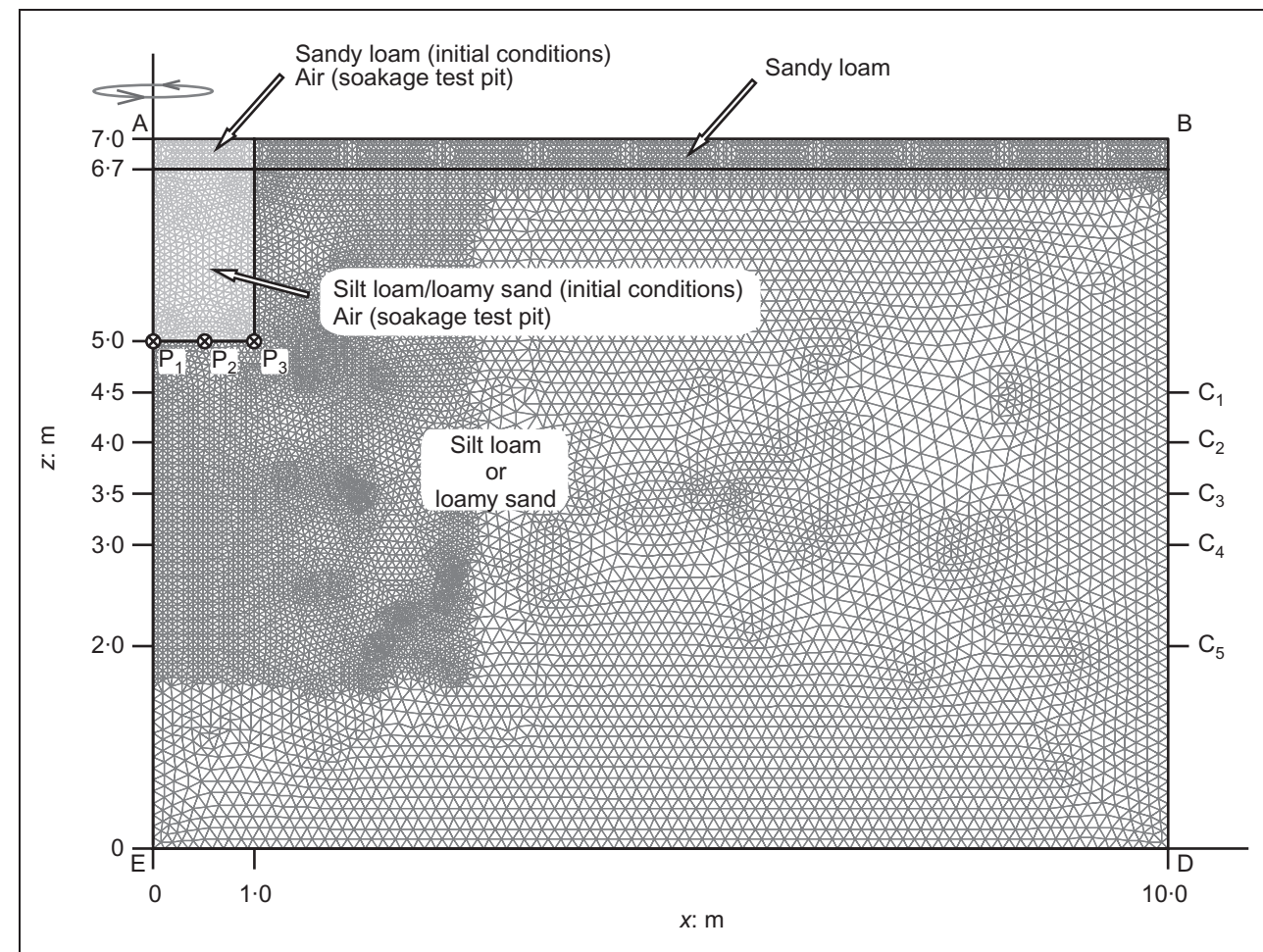

Figure I. Radial section of modelled domain showing geometry, finite element mesh and material distribution. The section is rotated about the Z-axis. Gravity is in the negative z-direction likely to experience high hydraulic gradients) and solution speed.

The subsoil (see Figure 1) was parameterised as either loamy sand or silt loam according to the scenario. These soils have contrasting hydraulic conductivity and soil water retention functions (see Figure 2), but both are suitable for infiltration drainage. ${ }^{4}$ A higher permeability sandy loam was selected for the $30 \mathrm{~cm}$ deep topsoil. The unsaturated hydraulic conductivity-pressure head relationship, $K(h)$, was specified using the Mualem ${ }^{19}$ formulation, combined with either the Brooks and Corey ${ }^{20}$ or the van Genuchten ${ }^{21}$ soil moisture retention function, $\theta(h)$, as appropriate; these two formulations are hereafter referred to as BC-M and VG-M respectively. Each of the soils was parameterised using mean values. ${ }^{22}$ However, given shortcomings in the original VG-M functions ${ }^{23}$ when the pore-size distribution parameter $n_{\mathrm{vg}}$ is less than $1 \cdot 3$ (Vogel et $a l .{ }^{24}$ ) or $2 \cdot 0$ (Ippisch et $a l .{ }^{25}$ ) (affecting both the silt loam and sandy loam), the parameters (Table 1) were converted from VG-M to BC-M using the relationships given in the RETC manual. ${ }^{26}$ The VG-M specification adopts the suggestion ${ }^{21}$ to specify the curve-fitting parameter

$$
3 \quad m_{\mathrm{vg}}=1-\left(1 / n_{\mathrm{vg}}\right)
$$

It also utilises Mualem's ${ }^{19}$ average $(0 \cdot 5)$ for the poreconnectivity parameter $l$.

The test pit volume was specified as soil during the initial condition simulations. During the soakage test simulations, this was replaced by a parameterisation for 'air' (or a 'highly permeable auxiliary material'). This follows other such parameterisations in transient saturated-unsaturated solutions to the Richards equation. ${ }^{27,28}$ The current specification (see

Table 1 and Figure 2) is an improvement on previous parameterisations, ${ }^{27}$ as the non-linearity of the $\theta(h)$ function is increased while maintaining a reasonably linear $K(h)$ function. Thus, accounting for water initially held above the test pit fill level, the water retained by capillarity in the unsaturated 'air' is reduced to $6 \%$ of the water input to the test pit. An even more non-linear specification of the $\theta(h)$ function was trialled, with $\alpha_{\mathrm{vg}}$ equal to $50 \mathrm{~m}^{-1}$, which further reduces the percentage of water retained. However, this doubled the simulation run time and there was less than $1 \%$ difference between trial infiltration coefficient calculations. The current 'air' parameterisation is therefore a reasonable compromise between 


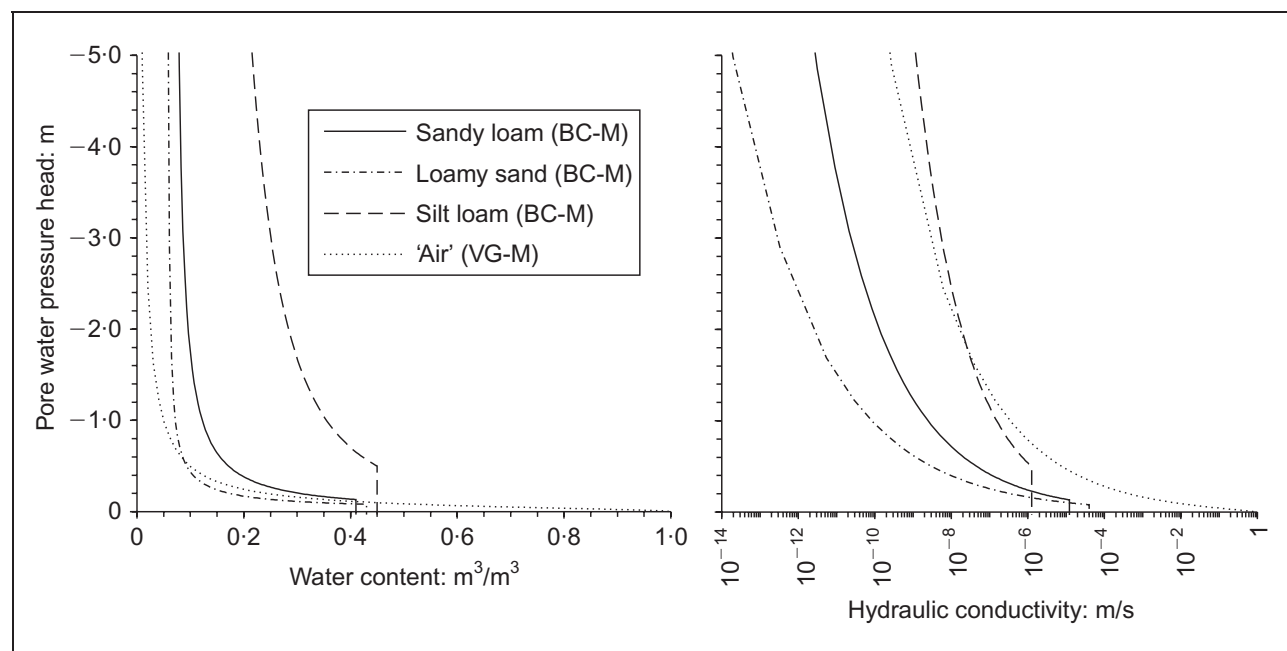

Figure 2. Material hydrological constitutive relationships (including 'air')

wetter even at some height above the water table. The surface boundary $(\mathrm{AB}$ in Figure 1) has a specified flux (Neumann) condition of $1.89 \times 10^{-3} \mathrm{~m} /$ day into the domain. This is equivalent to the average effective sixmonth 'winter' rainfall for southern England, ${ }^{29}$ assuming $0.5 \mathrm{~mm} /$ day evapotranspiration. The intermittent wetting and drying of the soil under successive rainfall events is thus represented by a constant flux. The lower right-hand boundary (along CD in Figure 1) has a

unsaturated 'air' water retention, computational speed and numerical stability.

\section{SOAKAGE TEST MODELLING}

A matrix of 20 soakage test scenarios was simulated. In the simulations, the sub-surface soil can be either loamy sand or silt loam, with the silt loam retaining more antecedent moisture than the loamy sand (see Figure 2). The season can be specified as either summer or winter. Five water table positions were considered: $0.5,1 \cdot 0,1.5,2.0$ and 3.0 m below the test pit base. The $0.5 \mathrm{~m}$ position was included because, although some guidance suggests that the seasonal high water table should remain at least $1 \mathrm{~m}$ below the base of the infiltration device, ${ }^{4,5}$ others suggest it need only be below the device. ${ }^{2,3}$

The first simulation stage was to specify the initial conditions for the subsequent transient soakage test. Summer initial conditions were directly specified as hydrostatic steady state with respect to the horizontal water table position because, assuming $2 \cdot 0 \mathrm{~mm}$ /day evapo-transpiration, the average effective six-month 'summer' rainfall for southern England ${ }^{29}$ is near zero. Therefore, with no surface boundary fluxes on average, no flows occur in the modelled domain and conditions remain hydrostatic.

Winter conditions were specified as (hydro-)dynamic steady state $^{30}$ following Blake and co-workers. ${ }^{13,31}$ This is also a 'hot start' approach. ${ }^{32}$ This specification allows for more realistic pressure heads (and hence soil moisture) in the unsaturated zone under recharge conditions. Thus, winter soils can remain specified head (Dirichlet) condition giving a hydrostatic pore water pressure head distribution below the water table position. For example, for an initial water table $1.0 \mathrm{~m}$ below the test pit base, the specified head boundary condition extends from $C_{2}$ to $\mathrm{D}$, with a hydraulic head value equal to $4.0 \mathrm{~m}$ elevation. All other boundaries are zero flux. The arbitrary initial pressure head distribution, used as a starting point to generate the hydrodynamic steady state, was set to hydrostatic with respect to the boundary water table position. A transient simulation was then allowed to run for a sufficient time (in this case 5000 days), using adaptive time-stepping, to achieve a hydrodynamic steady state. The generated conditions (e.g. Figure 3(a)) differ from a classic hydrostatic steady state as fluxes are crossing the model boundaries. However, the net boundary flux remains zero and hence the flows are steady state. As expected, for the same water table position, the unsaturated zone soil moisture is greater for winter conditions than summer and greater for silt loam than loamy sand.

The second simulation stage was to perform the soakage test procedure (see Section 1) for each initial condition scenario using transient simulations. The right-hand boundary (CD) remains hydrostatic with respect to the initial water table position and uses a specified head condition. This allows water to exit the domain. All other boundaries are zero flux. To simulate the test pit excavation, the relevant volumes of topsoil and subsoil were re-parameterised as 'air' (see Figure 1). The pit was then instantaneously filled with water to within $0.3 \mathrm{~m}$ of the surface (the proposed input pipe invert level) by changing the hydraulic head for the 'air' elements to $6.7 \mathrm{~m}$. The pit was

\begin{tabular}{|c|c|c|c|c|}
\hline \multirow[t]{2}{*}{ Parameter } & \multicolumn{4}{|c|}{ Material } \\
\hline & Sandy loam & Loamy sand & Silt loam & 'Air' \\
\hline$K_{\text {sat }}: \mathrm{m} / \mathrm{s}$ & $1.228 \times 10^{-5}$ & $4.053 \times 10^{-5}$ & $1.25 \times 10^{-6}$ & I \\
\hline$\theta_{s}: \mathrm{m}^{3} / \mathrm{m}^{3}$ & 0.41 & 0.43 & 0.45 & i \\
\hline$\theta_{\mathrm{r}}: \mathrm{m}^{3} / \mathrm{m}^{3}$ & 0.065 & 0.057 & 0.067 & $1 \times 10^{-6}$ \\
\hline$n_{b c}$ & 0.89 & $1 \cdot 28$ & 0.41 & - \\
\hline$\alpha_{\mathrm{bc}}: \mathrm{m}^{-1}$ & $7 \cdot 5$ & $12 \cdot 4$ & 2 & - \\
\hline$n_{v g}$ & - & - & - & 2 \\
\hline$\alpha_{\mathrm{vg}}: \mathrm{m}^{-1}$ & 一 & - & - & 20 \\
\hline
\end{tabular}



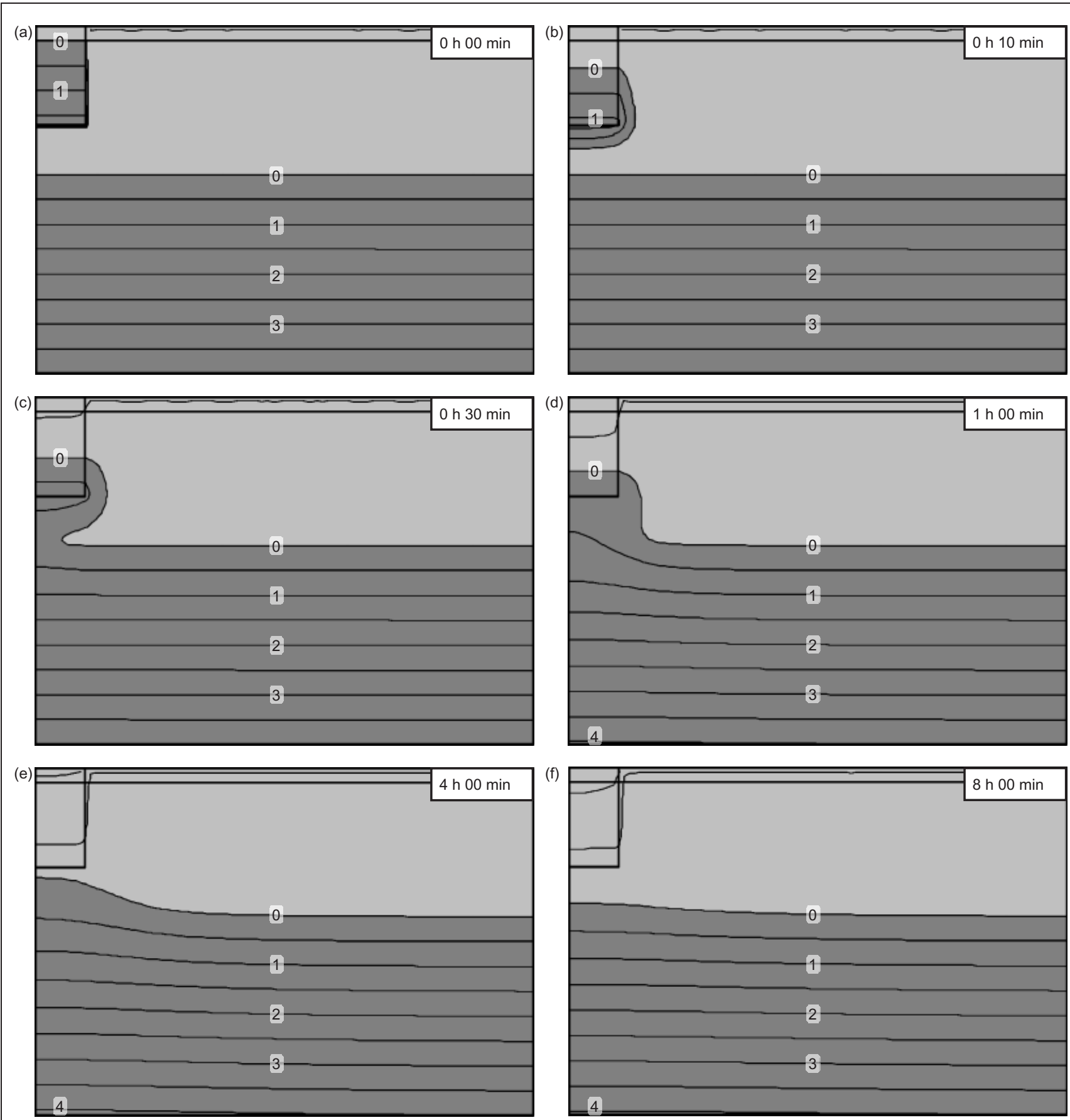

Figure 3. Transient soakage test simulation pore water pressure head distributions for example output time-steps (contours every $0.5 \mathrm{~m}$ ). Material distribution and dimensions as Figure I. The simulation is the first drain down for loamy sand in winter soil moisture conditions with the initial water table at $1.0 \mathrm{~m}$ below the test pit. Unsaturated material is light grey, saturated is dark

then allowed to drain using a transient simulation $(8 \mathrm{~h}$ for the loamy sand scenarios and $48 \mathrm{~h}$ for the silt loam scenarios). For the silt loam scenarios it was sometimes necessary to extend the simulated time (in one-day increments) until the pit had emptied. The water level drain down was monitored by recording the model state variables at each numerical time-step at points along the test pit base $\left(\mathrm{P}_{1}\right.$ to $\mathrm{P}_{3}$ in Figure 1$)$. Since the water in the test pit remains hydrostatic, the hydraulic head at these points represents the water surface elevation. Having completed the first drain down, the resultant pressure head distribution was used as the initial conditions for the next refill and drain down cycle. This was repeated once more, giving three successive drain downs. The matrix of simulations took some $350 \mathrm{~h}$ on a Pentium 4 PC.

\section{RESULTS}

A typical pore water pressure head development during a soakage test is shown in Figure 3. This shows the first drain down for the loamy sand, winter soil moisture, $1.0 \mathrm{~m}$ to initial water table, scenario. Initially the test pit is full. A bulb of saturation develops around the test pit by $10 \mathrm{~min}$ (Figure 3(b)). Infiltration is occurring through the pit sides and base. After $30 \mathrm{~min}$ (c), the infiltrating water has coalesced with the groundwater; this continues after $1 \mathrm{~h}$ (d). After $4 \mathrm{~h}$ (e) the pit has emptied, causing localised groundwater mounding. The water table has nearly returned to its initial position after $8 \mathrm{~h}$, although it is still somewhat elevated beneath the pit (f). This implies that there will be less available storage near the pit, slowing the next drain down and decreasing the infiltration coefficient. 
The drain down curve for the Figure 3 scenario, as measured at $\mathrm{P}_{1}$ (shown on Figure 1), is shown as the solid curve in Figure 4. The pit is full at $6.70 \mathrm{~m}$ and empty at $5.00 \mathrm{~m}$. The emptying rate slows over time. The infiltration coefficient $q$ was calculated as follows. From the plot, obtain the times when the pit is $75 \%$ full $(H=6.275 \mathrm{~m})$ and $25 \%$ full $(H=5.425 \mathrm{~m})$, that is 0.09984 and $1.19112 \mathrm{~h}$ respectively, making $t_{p 75-25}=$ $1.09128 \mathrm{~h}$. Given the problem geometry, $a_{p 50}=8.482 \mathrm{~m}^{2}$ and $V_{p 75-25}=2.670 \mathrm{~m}^{3}$. Thus, from Equation $1, q=0.288 \mathrm{~m} / \mathrm{h}$. Similar calculations were made for the other 59 drain downs. Figure 4 also shows that the drain down is quicker for a deeper initial water table (e.g. $3 \mathrm{~m}$ below the pit base) and slower for the third successive drain down.

Figures 5 and 6 show the calculated infiltration coefficients for each drain down in the 20 scenarios. They are all within the expected range, that is 0.01 to $1.0 \mathrm{~m} / \mathrm{h}$ for loamy sand and 0.0005 to $0.05 \mathrm{~m} / \mathrm{h}$ for silt loam. ${ }^{4,5}$ The calculated infiltration coefficient decreases over the three successive drain downs with the third repetition approaching a minimum. These minima are often significantly larger than the soil saturated hydraulic conductivity (see Table 1), implying that unsaturated zone water storage also exerts an important control on the empirical infiltration coefficient. By the third drain down, any difference due to summer or winter antecedent soil moisture has been greatly reduced, especially for the loamy sand. This is due to the volume of water entering the sub-surface during the test, masking seasonal antecedent soil moisture effects. The silt loams are also affected by a capillary fringe effect (the soil up to $0.5 \mathrm{~m}$ above the water table remains saturated while under tension; see the retention characteristic in Figure 2), reducing the available storage immediately above the water table regardless of summer or winter conditions. Thus, there is less difference between infiltration coefficients at shallow water

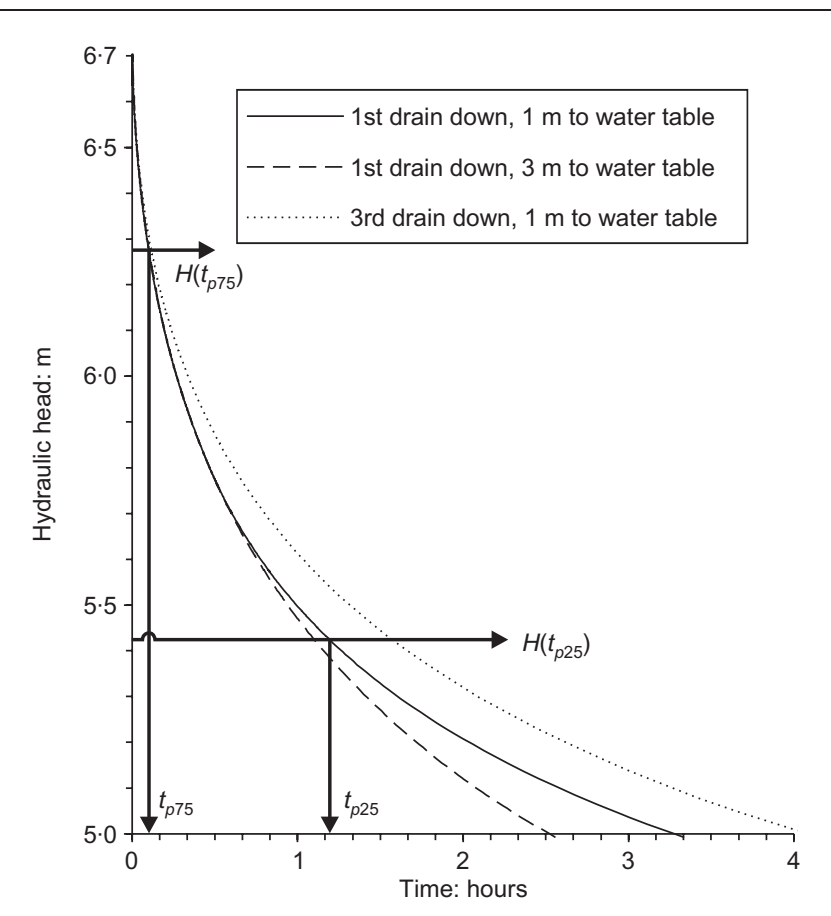

Figure 4. Example soakage test drain down plots, with varying drain down number and depth to water table, for loamy sand winter scenario. Hydraulic head values recorded at $P_{1}$ (see Figure I)

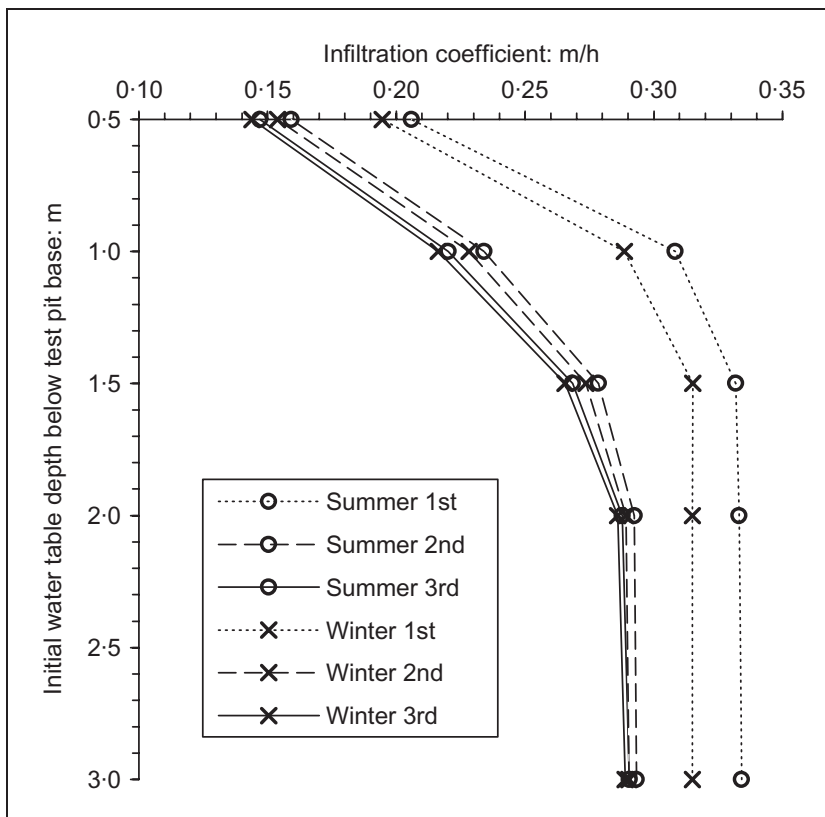

Figure 5. Loamy sand: calculated infiltration coefficients under varying initial soil moisture (winter and summer) conditions and varying initial water table positions. Results from the first, second and third successive drain downs are shown

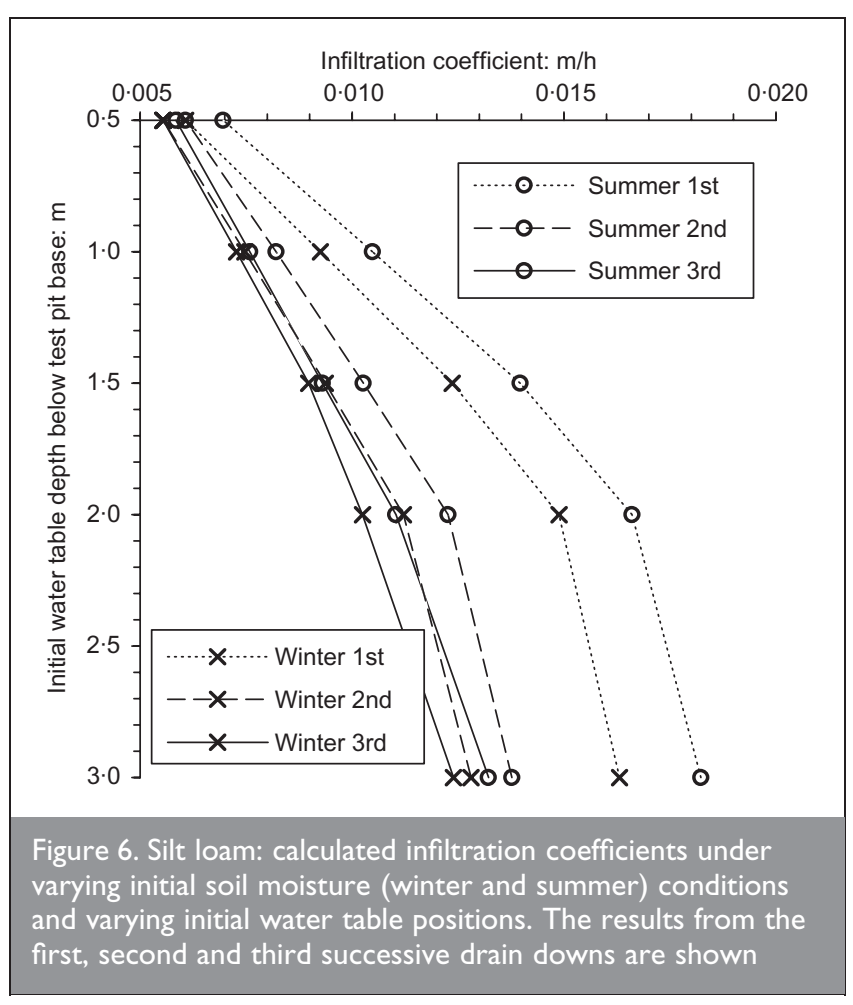

table depths. Considering the third drain down values, Figure 5 shows that loamy sand has a threshold initial water table depth (at $2.00 \mathrm{~m}$ ) above which the infiltration coefficient has a highly sensitive non-linear response to water table position. Below this threshold, it is insensitive. Figure 6 shows that infiltration coefficients for silt loam also have a sensitive, but more linear, response and any threshold position is below $3 \mathrm{~m}$. These behaviours reflect the differing soil water retention and unsaturated hydraulic conductivity functions.

Figures 7 and 8 show pit emptying times for the various scenarios. Initial water table position is a significant control, 


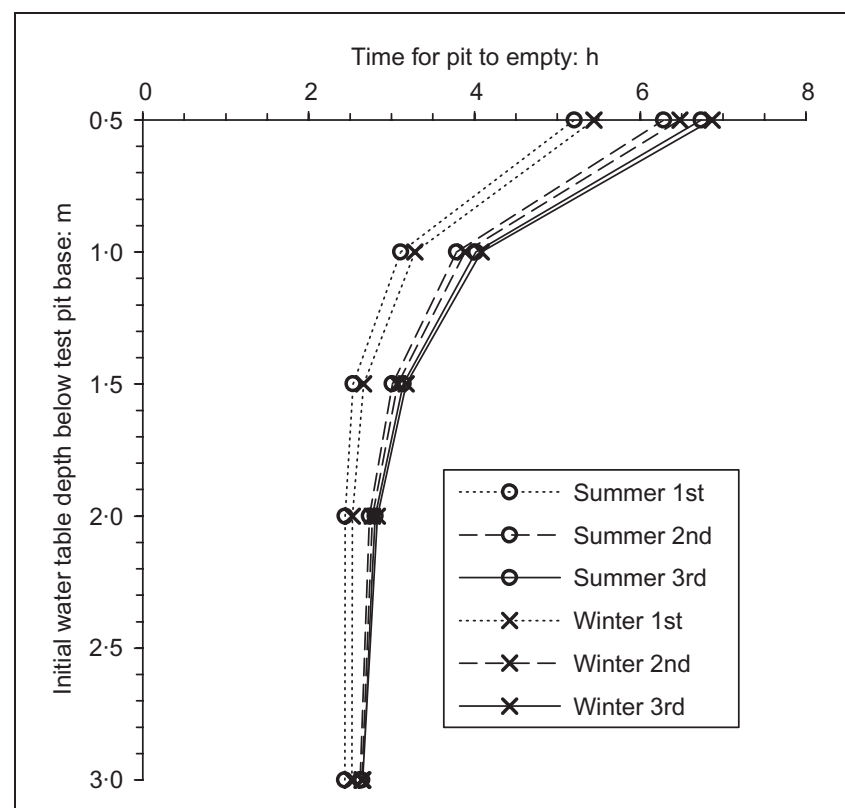

Figure 7. Loamy sand: times for soakage test pit to empty for varying initial soil moisture (winter and summer) conditions and varying initial water table positions. The results from the first, second and third successive drain downs are shown

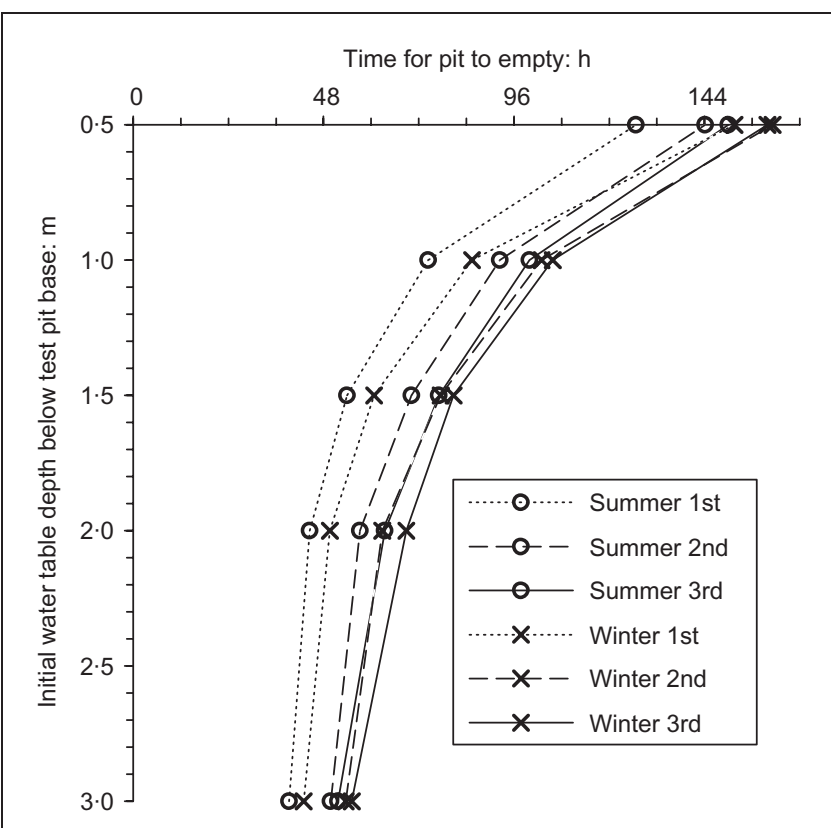

Figure 8. Silt loam: times for soakage test pit to empty for varying initial soil moisture (winter and summer) conditions and varying initial water table positions. The results from the first, second and third successive drain downs are shown

with soil moisture effects much less pronounced. While the three successive drain downs for the loamy sands were completed within $24 \mathrm{~h}$, the silt loams required between 1.5 and 7 days for each emptying. Current guidance recommends that infiltration devices either half empty within $24 \mathrm{~h}^{4,5}$ or totally empty within $48 \mathrm{~h} .{ }^{5}$ The long soakage test total emptying times for the silt loams do not necessarily preclude its use for infiltration drainage, as the emptying time for any constructed device will also be affected by the size of the drained area, selected design storm and the device dimensions. Furthermore, all silt loam scenarios half-emptied within $24 \mathrm{~h}$, except for the second and third drain downs for the winter scenario with the water table at $0.5 \mathrm{~m}$ below the pit base (these took $24 \mathrm{~h} 55 \mathrm{~min}$ and $25 \mathrm{~h} 5 \mathrm{~min}$, respectively).

\section{DISCUSSION}

The soakage test modelling described in this paper revealed that antecedent water table position, possibly above a threshold depth, exerts a significant control on the empirical infiltration coefficient. The effect of seasonal antecedent soil moisture is less significant, especially after three drain downs. Clearly, however, water table position and soil moisture are intrinsically linked as a higher water table position will increase the overall proportion of soil moisture in the unsaturated zone. Similar findings come from a trench infiltration modelling study, ${ }^{10}$ which, although limited to constant head infiltration, showed that high water table position and groundwater mounding reduces infiltration, while antecedent soil moisture was less important. Thus, soakage testing should ideally be performed during the most onerous antecedent water table conditions. The seasonal high water table is likely to occur in winter and will therefore be combined with wetter antecedent soil moisture conditions. This is supported by the limited soakage testing cited by Pratt, ${ }^{7}$ which found that winter infiltration rates could be one third of the summer value. However, it is now possible to recognise that water table position, rather than seasonal soil moisture, was the likely controlling factor in that case.

The control exerted by water table position has implications for soakage testing during periods of lower groundwater level (e.g. in droughts or summer) as the measured infiltration coefficient might be higher than otherwise expected. To account for this, information such as that given in Figures 5 and 6 could be used to reduce the infiltration coefficient used in design, providing an appropriate high winter water table position could be specified. In addition, current guidance ${ }^{5}$ recommends that SuDS should be designed to operate during periods of extreme (up to $1 \%$ annual probability) groundwater levels. Therefore, provided that data on the extreme groundwater level were available, outputs such as Figures 5 and 6 could again be used to quantify the necessary reduction in the design infiltration coefficient. It should be noted that if the anticipated high/extreme level is below the threshold depth, then no reduction would be necessary.

If antecedent hydrological conditions are not considered, the infiltration coefficient may be overestimated. For example, Figure 5 shows that for loamy sand under both winter and summer soil moisture conditions, if the infiltration coefficient (third drain down curve) were calculated when the water table was $2.00 \mathrm{~m}$ below the pit base, a subsequent water table rise to within $0.50 \mathrm{~m}$ of the base would reduce the infiltration coefficient by about 50\%. If it is uncertain whether the water table can actually rise to within $0.50 \mathrm{~m}$ of the pit base, the infiltration coefficient used in design should be reduced accordingly. However, there may be a threshold depth to the water table (e.g. $2 \cdot 00 \mathrm{~m}$ in Figure 5), varying according to soil type, beyond which the infiltration coefficient is invariant. Thus, providing the water table cannot rise above this threshold, reducing the infiltration coefficient would be unnecessary. 
The results have additional implications for soakage testing practice.

(a) The above discussion has assumed that soakage tests follow best practice ${ }^{3-5}$ by making three successive drain downs, using the smallest infiltration coefficient in design. However, often only one drain down is used in practice. Figures 5 and 6 show that the infiltration coefficient for the first drain down may be significantly larger than that for the third. Furthermore, the first drain down will be more affected by seasonal antecedent soil moisture. Therefore, improper soakage testing can significantly overestimate the infiltration coefficient. For example, for the silt loam with summer antecedent soil moisture and $2.00 \mathrm{~m}$ to the water table (Figure 6), the third drain down infiltration coefficient is actually two-thirds of that for the first drain down.

(b) The recommendation to complete three drain downs on the same day ${ }^{4,5}$ may not be achievable for some soils, even though they are suitable for infiltration drainage. For example, test pit emptying for the silt loams took a surprisingly long time (Figure 8), even though the calculated infiltration coefficients were within the expected range.

The current infiltration coefficient calculation (Equation 1) accounts for the time the test pit takes to drain from 75 to $25 \%$ of the effective depth and the associated volume change.

However, as shown in Figure 4, the rate of drain down slows as the pit empties. Therefore, the current calculation will be biased towards the initial, more rapid, infiltration rate. Indeed, the model results show that the drain down curves can be particularly non-linear, with long tails, for higher water table positions, winter soil moisture conditions and silt loam soil. This is supported by the observed drain down curve given in BRE digest $365 .^{3}$ Watkins' falling head simulation drain down plots $^{6}$ also display non-linearity, although to a lesser extent, possibly reflecting the absence of water table effects. A more representative infiltration coefficient could be calculated by using the time and volume for the test pit to drain from full to empty, thus giving the 'full-depth' infiltration coefficient equation

\begin{tabular}{|c|c|}
\hline 4 & $q=V_{p 100-0} /\left(a_{p 50} \times t_{p 100-0}\right)$ \\
\hline
\end{tabular}

where $V_{p 100-0}$ is the volume of the pit between 100 and $0 \%$ of the effective depth and $t_{p 100-0}$ is the time for the water level to fall from 100 to $0 \%$ of the effective depth. Using this instead of Equation 1 will avoid bias in the calculated infiltration coefficient. It should be remembered that determination of the infiltration coefficient using soakage testing is independent of the design method to be adopted, whether BRE digest $365{ }^{3}$ CIRIA report $156,{ }^{4}$ the SuDS manual ${ }^{5}$ or an alternative. On a practical note, this equation requires the complete pit emptying to be timed, which will take longer than emptying to $25 \%$ of effective depth. Furthermore, it may be difficult to ascertain the exact moment when a test pit is totally full or totally empty, meaning that measurements from 'practically full' to 'practically empty' may be more appropriate. As shown in Figures 9 and 10, the proposed full-depth infiltration coefficient calculation gives values $8-36 \%$ lower than the

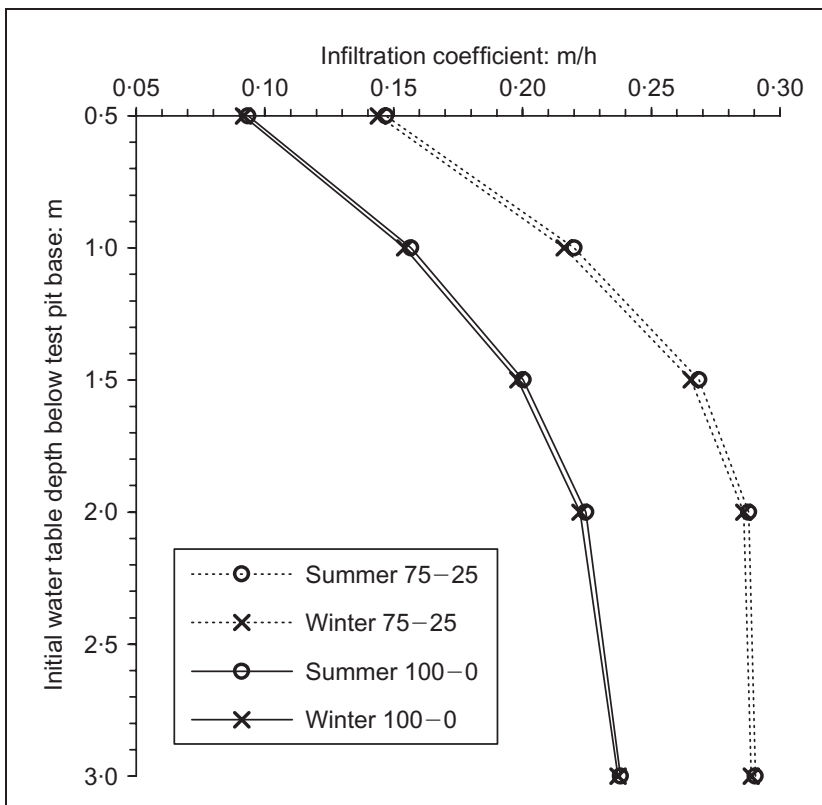

Figure 9. Loamy sand: infiltration coefficients under varying initial soil moisture (winter and summer) conditions and varying initial water table positions. The results shown are for the third drain down and were calculated using both the original infiltration coefficient equation (Equation I) (labelled $75-25)$ and the full-depth equation (Equation 4) (100-0)

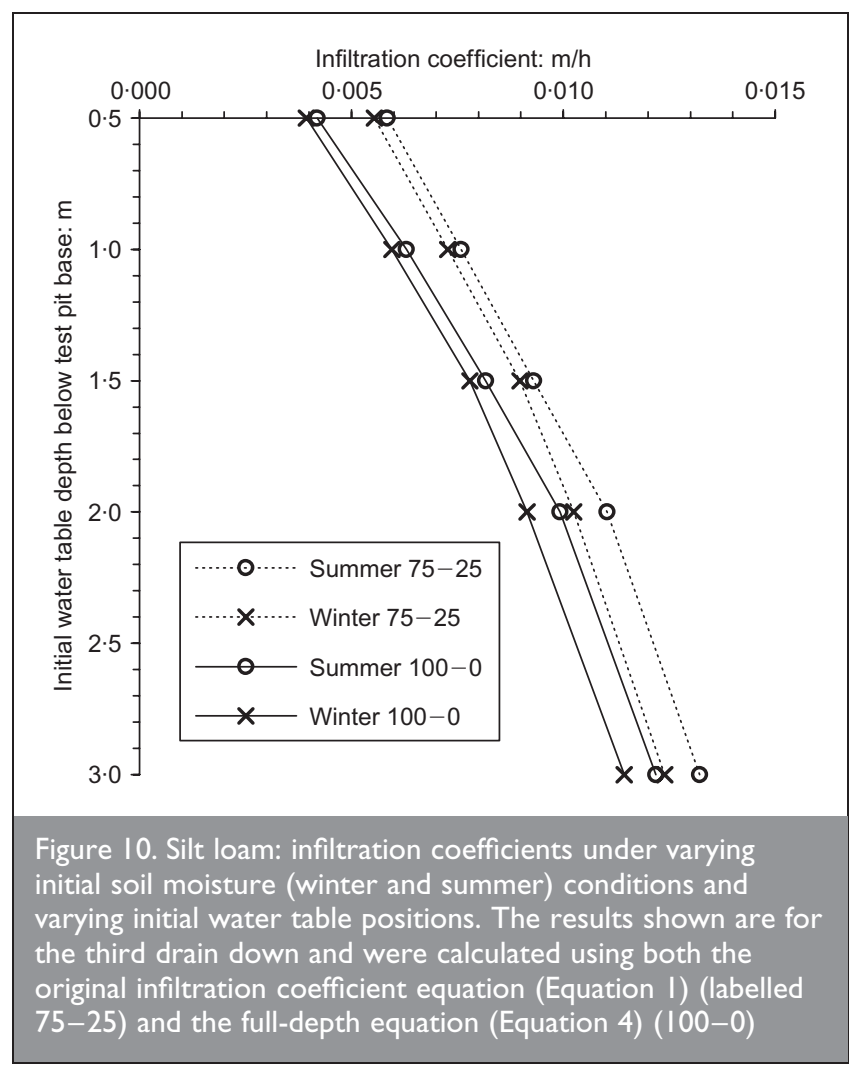

original formulation, removing the bias. The values are still within the expected ranges. Furthermore, the previous trends, in terms of relative sensitivities to water table position and soil moisture, have been preserved, meaning that the previous discussion remains valid.

The identified infiltration coefficient sensitivity to antecedent water table position may also have implications for infiltration 
drainage performance. Specifically, if rainfall is collected to infiltrate over a smaller area, for certain sub-surface conditions there may be a persistent localised water table rise centred on the infiltration device (i.e. groundwater mounding ${ }^{8,12,33}$ ). This would cause a detrimental feedback, whereby a higher water table would reduce the infiltration coefficient, thereby reducing the infiltration device performance. This, along with bias in the traditional infiltration coefficient calculation, may explain why infiltration devices can be slow to empty fully (e.g. Abbott and Comino-Mateos ${ }^{34}$ ). This feedback would not be accounted for by soakage testing as potential groundwater mounding would only occur after installation of the infiltration device. Of course, the drained areas no longer directly recharge the groundwater; therefore the water table may be lower further away from the device. Hence the behaviour would be affected by the dynamic interaction between flow events, groundwater levels and hydraulic gradients. Although it is suggested that the combined effect of infiltration devices should not exceed the overall soakage capacity of the ground, ${ }^{2}$ this potential feedback on the infiltration coefficient has been hitherto unrecognised.

Finally, while infiltration coefficient overestimation caused by using only a single soakage test drain down (instead of three) and by using the current infiltration coefficient equation (instead of the proposed full-depth version) have been discussed separately, they actually have a cumulative effect. For the above scenarios, to account for this effect, the calculated infiltration coefficients would need to be reduced by $25-55 \%$. This is in addition to any reductions due to infiltration coefficient reduction over time, ${ }^{5}$ potential detrimental feedback due to groundwater mounding and uncertainty over the maximum water table height.

\section{CONCLUSIONS}

This research has used numerical modelling to investigate the control that seasonal antecedent hydrological conditions, specifically unsaturated zone soil moisture and water table position, have on the empirical soil infiltration coefficient determined using the current soakage test procedure. The key findings are as follows.

(a) Antecedent water table position exerts an important control on the infiltration coefficient. There may also be a threshold water table position, varying according to soil type, above which the relationship is sensitive and below which it is not.

(b) Seasonal antecedent soil moisture variability is less important, providing that the soakage test procedure is performed according to best practice guidance ${ }^{3-5}$ (i.e. uses three successive drain downs, allowing the infiltration coefficient to approach a minimum value).

(c) Soakage testing should ideally be performed under the most onerous hydrological conditions, usually in the winter.

(d) Model outputs of the type generated in this work can be used to reduce the infiltration coefficient used in design to account for: tests made during periods of lower groundwater level (e.g. droughts or summer); a higher design extreme groundwater level $;^{5}$ and uncertainty over the maximum water table height. If the anticipated high/ extreme level is below the threshold depth (e.g. $2 \cdot 00 \mathrm{~m}$ below the device base for loamy sand), then no reduction would be necessary.

(e) Soakage testing must use three successive drain downs (confirming current guidance ${ }^{3-5}$ ). If only one is used, the resultant infiltration coefficient will be significantly overestimated. However, three drain downs on the same day $^{4,5}$ may be unachievable.

$(f)$ The current infiltration coefficient calculation (Equation 1) is biased towards the more rapid initial infiltration rate. To avoid this bias, the proposed full-depth infiltration coefficient calculation (Equation 4) should be used instead.

(g) It has been hypothesised that under certain circumstances there could be detrimental feedback between groundwater mounding caused by an infiltration device and the performance of that device. This would not be accounted for by the soakage test procedure.

Future research should consider expanding the range of modelled scenarios in terms of soil types and water table positions. Relationships between water table depth and infiltration coefficient (e.g. Figures 5 and 6) could thus be defined for a range of soils. These could be used in practice to reduce the design infiltration coefficient to account for both tests made during periods of lower groundwater level and higher design water table positions. Threshold water table depths for different soils could also be established. Knowing that water table position is the fundamental antecedent hydrological control on the infiltration coefficient, it would be instructive to perform field soakage tests over an annual cycle. Perhaps testing could be carried out in a river floodplain location, where seasonal water table fluctuations could be expected and monitored. Finally, the hypothesised detrimental feedback between infiltration device performance and groundwater mounding should be investigated. For example, a site could be monitored before and after installation of infiltration drainage or exploratory numerical modelling could be used to investigate the dynamic interactive processes.

\section{ACKNOWLEDGEMENTS}

The work presented in this paper was developed under Water cycle management for New Developments (WaND) and project support from the EPSRC and industrial collaborators is acknowledged. NERC provided additional support. The author would also like to thank John Packman for useful discussion and comments on an earlier draft of this paper and the anonymous reviewers for their helpful comments.

\section{REFERENCES}

1. Department For Communities And Local Government. Planning Policy Statement 25: Development and Flood Risk. The Stationery Office, Norwich, 2006.

2. OfFICE OF THE DEPUTY PRIME Minister. The Building Regulations 2000, Approved Document H, Drainage and waste disposal. NBS, Newcastle upon Tyne, 2002.

3. BuILDIng RESEARCH Establishment. Soakaway Design. BRE, Watford, 1991, Digest 365.

4. BetTeSS R. Infiltration Drainage: Manual of Good Practice. Construction Industry Research and Information Association, London, 1996, Report 156.

5. Woods-Ballard B., Kellagher R., Martin P., JefFeries C., BRAY R. and SHAFFER P. The SUDS Manual. Construction 
Industry Research and Information Association, London, 2007, C697.

6. WATKINS D. C. The Hydraulic Design and Performance of Soakaways. HR Wallingford, Wallingford, 1991, SR 271.

7. PRATT C. J. Research and development in methods of soakaway design. Journal of the Chartered Institution of Water and Environmental Management, 1996, 10, No. 1, 47-51.

8. ÖNDER H. and KORKMAZ S. Groundwater mound due to constant recharge from a strip basin. Journal of Hydrologic Engineering, 2007, 12, No. 3, 237-245.

9. HeRATH S. and MusiaKe K. Simulation of basin-scale runoff reduction by infiltration systems. Water Science and Technology, 1994, 29, No. 1-2, 267-275.

10. Duchene M., McBean E. A. and Thomson N. R. Modeling of infiltration from trenches for storm-water control. ASCE Journal of Water Resources Planning and Management, 1994, 120, No. 3, 276-293.

11. VAUClin M., KhanjI D. and VACHAUd G. Experimental and numerical study of a transient, two-dimensional unsaturated-saturated water table recharge problem. Water Resources Research, 1979, 15, No. 5, 1089-1101.

12. Sumner D. M., Rolston D. E. and Mariño M. A. Effects of unsaturated zone on ground-water mounding. Journal of Hydrologic Engineering, 1999, 4, No. 1, 65-69.

13. BlaKe J. R., RENAUd J.-P., ANDERSON M. G. and Hencher S. R. Prediction of rainfall-induced transient water pressure head behind a retaining wall using a high-resolution finite element model. Computers and Geotechnics, 2003, 30, No. 6, 431-442.

14. Celia M. A., Bouloutas E. T. and Zarba R. L. A general mass-conservative numerical-solution for the unsaturated flow equation. Water Resources Research, 1990, 26, No. 7, $1483-1496$.

15. See http://www.feflow.info

16. DiersCH H.-J. G. Feflow ${ }^{\circledR}$ Reference Manual. WASY, Berlin, 2002.

17. Diersch H.-J. G., SChÄTZl P., GrÜNDLER R. and ClAusNitZER V. Feflow $^{\circledR}$ 5.2 User's Manual. WASY, Berlin, 2005.

18. DiersCH H.-J. G. (ed.). Feflow ${ }^{\circledR}$ White Papers Vol. I. WASY, Berlin, 2004.

19. Mualem Y. A new model for predicting the hydraulic conductivity of unsaturated porous media. Water Resources Research, 1976, 12, No. 3, 513-522.

20. Brooks R. H. and Corey A. T. Hydraulic Properties of Porous Media. Colorado State University, Fort Collins, CO, 1964, Hydrology paper no. 3.

21. VAN GENUCHTEN M. T. A closed-form equation for predicting the hydraulic conductivity of unsaturated soils. Soil Science Society of America Journal, 1980, 44, No. 5, 892-898.

22. CARSEL R. F. and PARRISH R. S. Developing joint probability distributions of soil-water retention characteristics. Water Resources Research, 1988, 24, No. 5, 755-769.

23. SchaAp M. G. and VAn GenUChten M. T. A modified Mualem-van Genuchten formulation for improved description of the hydraulic conductivity near saturation. Vadose Zone Journal, 2006, 5, No. 1, 27-34.

24. Vogel T., van Genuchten M. T. and Cislerova M. Effect of the shape of the soil hydraulic functions near saturation on variably-saturated flow predictions. Advances in Water Resources, 2000, 24, No. 2, 133-144.

25. IPpisch 0., Vogel H. J. and Bastian P. Validity limits for the van Genuchten-Mualem model and implications for parameter estimation and numerical simulation. Advances in Water Resources, 2006, 29, No. 12, 1780-1789.

26. VAn Genuchten M. T., LeiJ F. J. and Yates S. R. The RETC Code for Quantifying the Hydraulic Functions of Unsaturated Soils. US Environmental Protection Agency, Oklahoma, 1991, EPA/600/2-91/065.

27. DiERSCH H.-J. G. Treatment of free surfaces in 2D and 3D groundwater modeling. In Feflow White Papers Vol. I (DiersCh H.-J. G. (ed.)). WASY, Berlin, 2004, pp. 67-100.

28. Göbel P., Stubbe H., Weinert M., Zimmermann J., Fach S., Dierkes C., Kories H., Messer J., Mertsch V., Geiger W. F. and CoLDEWEY W. G. Near-natural stormwater management and its effects on the water budget and groundwater surface in urban areas taking account of the hydrogeological conditions. Journal of Hydrology, 2004, 299, No. 3-4, 267-283.

29. See http://www.metoffice.gov.uk/climate/uk/averages/ 19712000/areal/england_s.html

30. ANDERSON M. P. and WoESSNER W. W. Applied Groundwater Modeling-Simulation of Flow and Advective Transport. Academic Press, San Diego, 1992.

31. BlaKe J. R. Modelling the Dynamic Interaction between Hillslope Hydrology and Retaining Structures (Hydrology and Retaining Wall Stability Model: HYDRET). PhD thesis, University of Bristol, 2003.

32. Cloke H. L., Renaud J.-P., Claxton A. J., McDonnell J., ANDERSON M. G., BlaKe J. R. and BATES P. D. The effect of model configuration on modelled hillslope-riparian interactions. Journal of Hydrology, 2003, 279, No. 1-4, $167-181$.

33. Rai S. N., Ramana D. V., Thiagarajan S. and Manglik A. Modelling of groundwater mound formation resulting from transient recharge. Hydrological Processes, 2001, 15, No. 8, $1507-1514$.

34. Аввотт C. L. and Comino-Mateos L. In situ performance monitoring of an infiltration drainage system and field testing of current design procedures. Journal of the Chartered Institution of Water and Environmental Management, 2001, 15, No. 3, 198-202.

\section{What do you think?}

To comment on this paper, please email up to 500 words to the editor at journals@ice.org.uk

Proceedings journals rely entirely on contributions sent in by civil engineers and related professionals, academics and students. Papers should be 2000-5000 words long, with adequate illustrations and references. Please visit www.thomastelford.com/journals for author guidelines and further details. 